\title{
Ankle and Toe Brachial Index Extraction from Clinical Reports For Peripheral Artery Disease Identification: Unlocking Clinical Data through Novel Methods
}

Julia E. Friberg* MPH; Abdul H. Qazi* MD; Brenden Boyle MD; Carrie Franciscus MA; Mary Vaughan-Sarrazin PhD; Dax Westerman, MS; Olga V. Patterson PhD; Sharidan K. Parr, MD, MSCI, MS; Michael E. Matheny MD, MPH; Shipra Arya MD, SM; Kim G. Smolderen PhD; Brian C. Lund PharmD; Glenn T. Gobbel DVM, PhD, MS ${ }^{\$}$ Saket Girotra MD, SM ${ }^{\$}$

Center for Access and Delivery Research and Evaluation, lowa City Veterans Affairs Medical Center (JEF, CF, MVS, BCL, SG) and Department of Medicine, University of lowa Carver College of Medicine (MVS, SG), lowa City, IA; Massachusetts General Hospital, Boston, MA (AHQ); Division of Cardioscular Medicine, University of Minnesota, Minneapolis, MN (BB); Salt Lake City Veterans Affairs Medical Center, Salt Lake City, UT (OVP); Tennessee Valley Healthcare System (MEM, GTG) and Vanderbilt University Medical Center (DW, SKP, MEM, GTG), Nashville, TN; Palo Alto Veterans Affairs Medical Center and Stanford University, Palo Alto, CA (SA); Department of Medicine and Psychiatry, Yale University School of Medicine, New Haven, CT (KGS)

*Julia E. Friberg and Abdul H. Qazi contributed equally to this manuscript

\$Glenn T. Gobbel and Saket Girotra contributed equally to this manuscript

\section{Co-corresponding Authors:}

Saket Girotra MD, SM

200 Hawkins Drive, Suite 4427 JCP

Division of Cardiovascular Diseases, University of lowa

lowa City, IA 52242

saket-girotra@uiowa.edu

Glenn T. Gobbel, DVM, PhD, MS

$4^{\text {th }}$ Floor, GRECC, Tennessee Valley Health System

1310 24th Ave S, Nashville, TN 37212

glenn.t.gobbel@vanderbilt.edu

Abstract Word Count: 349

Manuscript word count: 3772

NOTE: This preprint reports new research that has not been certified by peer review and should not be used to guide clinical practice. 
medRxiv preprint doi: https://doi.org/10.1101/2021.05.08.21256421; this version posted May 10, 2021. The copyright holder for this preprint (which was not certified by peer review) is the author/funder, who has granted medRxiv a license to display the preprint in perpetuity.

All rights reserved. No reuse allowed without permission.

\section{ABSTRACT}

Importance: Despite its high prevalence and poor outcomes, research on peripheral artery disease (PAD) remains limited due to the poor accuracy of billing codes for identifying PAD in health systems.

Objective: Design a natural language processing (NLP) system that can extract ankle brachial index $(A B I)$ and toe brachial index $(\mathrm{TBI})$ values and evaluate the performance of extracted $\mathrm{ABI} / \mathrm{TBI}$ values to identify patients with PAD in the Veterans Health Administration (VHA).

Design, Setting, Participants: From a corpus of 392,244 ABI test reports at $94 \mathrm{VHA}$ facilities during 2015-2017, we selected a random sample of 800 documents for NLP development. Using machine learning, we designed the NLP system to extract $A B I$ and TBI values and laterality (right or left). Performance was optimized through sequential iterations of 10 -fold cross validation and error analysis on 3 sets of 200 documents each, and tested on a final, independent set of 200 documents.

Performance of NLP-extracted $\mathrm{ABI}$ and TBI values to identify PAD in a random sample of Veterans undergoing $\mathrm{ABI}$ testing was compared to structured chart review.

Exposure: $\mathrm{ABI} \leq 0.9$, or $\mathrm{TBI} \leq 0.7$ in either right or left limb was used to define $\mathrm{PAD}$ at the patient-level Main Outcome: Precision (or positive predictive value), recall (or sensitivity), F-1 measure (overall measure of accuracy, defined as harmonic mean of precision and recall)

Results: The NLP system had an overall precision of 0.85 , recall of 0.93 and F1-measure of 0.89 to correctly identify $\mathrm{ABI} / \mathrm{TBI}$ values and laterality. The F-1 measure was similar for both $\mathrm{ABI}$ and $\mathrm{TBI}(0.88$ to 0.91$)$. Recall was higher for $\mathrm{ABI}(0.95$ to 0.97$)$ while precision was higher for TBI (0.94 to 0.95$)$. Among 261 patients with ABI testing (49\% with PAD), the NLP system achieved a positive predictive value of $92.3 \%$, sensitivity of $83.1 \%$ and specificity of $93.1 \%$ to identify PAD when compared to a structured chart review.

Conclusion: We have successfully developed and validated an NLP system to extract ABI and TBI values which can be used to accurately identify PAD within the VHA. Our findings have broad implications for PAD research and quality improvement efforts in large health systems. 
medRxiv preprint doi: https://doi.org/10.1101/2021.05.08.21256421; this version posted May 10, 2021. The copyright holder for this preprint (which was not certified by peer review) is the author/funder, who has granted medRxiv a license to display the preprint in perpetuity.

All rights reserved. No reuse allowed without permission.

\section{INTRODUCTION}

Lower extremity peripheral artery disease (PAD) is a common and highly morbid condition, ${ }^{1}$ affecting an estimated 12.5 million people in the U.S. PAD is associated with high mortality, and is a leading cause of disability due to the associated risk of cardiovascular (CV) and limb events. ${ }^{2-8}$ The economic burden of PAD is enormous - the total annual cost of PAD due to hospital care alone was $>\$ 21$ billion in $2004,{ }^{9-11}$ and these costs are likely higher in 2021.

Contemporary research on PAD using electronic health record (EHR) data within large integrated health systems has been limited by the poor sensitivity $(<40 \%)$ and specificity $(60-70 \%)$ of billing codes for identifying PAD patients. ${ }^{12,13}$ In contrast, the ankle-brachial index (ABI), a commonly used test for PAD diagnosis, has a high sensitivity ( 80\%) and specificity (96\%) for identifying PAD, which can be further enhanced with the addition of toe-brachial index (TBI). ${ }^{14}$ Moreover, $\mathrm{ABI}$ values represent an objective measure of leg ischemia, are associated with symptom severity and risk of CV

events, and also influence treatment decisions (e.g., revascularization). ${ }^{15-19}$ However, information on $A B I$ and $T B I$ values is commonly embedded in free text of the $A B I$ test reports in the EHR and not directly available for research in most health systems. Manual extraction of ABI values can be timeconsuming, limited by fatigue among human annotators and not practical in large health systems.

We developed and validated a natural language processing (NLP) system to extract $\mathrm{ABI}$ and TBI values from test reports obtained from 94 Veterans Affairs (VA) facilities. The NLP system uses machine learning-generated random forest models trained specifically to extract $A B I$ and $T B I$ values, assign laterality (right or left), and distinguish current from historical values from $A B I$ test reports. We also evaluated the performance of an algorithm based on NLP-extracted $A B I$ and TBI values to identify PAD in Veterans undergoing $A B I$ testing.

\section{METHODS}

\section{Setting and context}

The study was conducted in the Veterans Health Administratin (VHA), which comprises 130 VA medical centers. The VA Corporate Data Warehouse (CDW) is a national repository that includes EHR data 
medRxiv preprint doi: https://doi.org/10.1101/2021.05.08.21256421; this version posted May 10, 2021. The copyright holder for this preprint (which was not certified by peer review) is the author/funder, who has granted medRxiv a license to display the preprint in perpetuity.

All rights reserved. No reuse allowed without permission.

from all clinical encounters. Within the VHA, ABI tests are either performed in primary care, vascular surgery, or radiology depending on each site. Therefore, depending on the clinical department that performs the test, $\mathrm{ABI}$ test reports can be found in either Text Integration Utility (TIU) or Radiology domain in the CDW. We obtained data for all Veterans who had a TIU or a Radiology note entered in the CDW between 2015-2017. This work was approved by the Institutional Review Board and Research \& Development Committee at both the lowa City and Tennessee Valley VA.

\section{NLP System Design}

\section{Document Selection}

We designed the NLP system to extract $A B I$ and $T B I$ values from $A B I$ test reports rather than general clinical documents (e.g., clinic or consult notes) because $A B I$ test reports represent the "source document" for these results in the EHR corresponding to the test performed on a given date. This approach permits the use of the date of the first abnormal $A B I$ value as a surrogate for date of PAD onset, eliminates errors due to transcribing $A B I$ data from test reports to clinical notes and avoids the ambiguity in distinguishing current $A B I$ value from historical values which are commonly found in clinical notes. The overall approach is outlined in Figure 1. Details of the search strategy for identifying document titles used for reporting $A B I$ test results from the Radiology and the TIU domain are included in the Appendix (eMethods Section 1.1 \& eTable 1). A total of 224 document titles were identified from 94 out of 130 (72\%) VA facilities which represented 392,244 documents on 222,033 unique patients during 2015-2017 in the VHA. We also found that some VA sites used a generic document title to report ABI and other vascular studies (e.g., 'Vascular Studies' note title for reporting all vascular studies including carotid, renal, mesenteric, along with $\mathrm{ABI}$ ). We included documents associated with such generic titles in our final corpus for NLP training and testing to ensure that our tool could differentiate $A B I$ test reports from other non-ABI vascular studies that use the same document title. Documents used for reporting $A B I$ results could not be identified from 36 facilities primarily because they did not perform $A B I$ testing (small facilities) or scanned $A B I$ reports and stored them as images which are not available for research purposes) 
medRxiv preprint doi: https://doi.org/10.1101/2021.05.08.21256421; this version posted May 10, 2021. The copyright holder for this preprint (which was not certified by peer review) is the author/funder, who has granted medRxiv a license to display the preprint in perpetuity.

All rights reserved. No reuse allowed without permission.

\section{Annotation}

From the total corpus of $392,244 \mathrm{ABI}$ test reports during 2015-2017, we selected a random sample of 800 documents. Randomization was stratified to ensure that at least 5 documents were selected from each facility, with the remainder weighted by each facility's volume of $A B I$ test reports. The 800 reports were then separated into 4 sets of 200 documents each. A total of 600 documents were used for iterative NLP development and training and the remaining 200 documents were used for final testing.

Annotation was performed by two human annotators (JEF and AHQ). The goal of the annotation was to identify and categorize index type (ABI or TBI), index values, and laterality (right or left). Some $\mathrm{ABI}$ reports also included segmental blood pressure ratios, i.e., the ratio of blood pressure at the thigh or calf with arm blood pressure. Reviewers annotated these as 'non-index' values and the NLP system was deisgned to differentiate them from index $(\mathrm{ABI}$ or $\mathrm{TBI})$ values using features of the surrounding text (e.g. "thigh index"). Reviewers also annotated ABI or TBI values in the reports that represent values from a prior study as "historical values". All annotations were performed using eHOST software. ${ }^{20}$ Additional details regarding annotations are included in the Appendix (eMethods Section 1.2)

\section{NLP Development \& Evaluation}

The NLP tool uses regular expressions to label phrases commonly associated with the concept of ABI or $\mathrm{TBI}$, their values, and laterality and uses a machine learning approach (random forest) for identification of the above concepts. A major challenge that we encountered was that $\mathrm{ABI}$ and $\mathrm{TBI}$ values were often reported in a semi-structured format (e.g., table). A rule-based approach, which relies on the proximity of the concept of $\mathrm{ABI}$ and $\mathrm{TBI}$ to its corresponding value and laterality is limited in a tabular format where the $\mathrm{ABI}$ values are often distant from the concept of $\mathrm{ABI}$ (usually a table row or a column header). To overcome this challenge, we designed our NLP system to search for ABI or TBI values that may be in vertical (column) or horizontal (row) alignment with the concept of $\mathrm{ABI}$ and TBI, and laterality, rather than just in close proximity of their respective values. Details of the NLP system design are included in the Appendix (eMethods Section 1.3 and eTable 2). 
medRxiv preprint doi: https://doi.org/10.1101/2021.05.08.21256421; this version posted May 10, 2021. The copyright holder for this preprint (which was not certified by peer review) is the author/funder, who has granted medRxiv a license to display the preprint in perpetuity.

All rights reserved. No reuse allowed without permission.

We adapted source code provided by the Weka Workbench to develop, train, and evaluate random forest models. ${ }^{21}$ We have made our code publicly available on Github. ${ }^{22}$ Two distinct models were trained, one for assigning index type and another for assigning laterality to candidate index values. Only values that were positively classified with respect to both index type $(\mathrm{ABI}$ or $\mathrm{TBI})$ and laterality (left or right) were categorized as predicted index values (Figure 2). Random forest model hyperparameters were manually adjusted for each model using a grid search to maximize performance, which was quantified by comparing index values identified by the tool to those in the reference standard.

We employed an iterative process for tool development. After generating initial text patterns for feature extraction, we trained a random forest model on the first set of 200 documents and evaluated the trained model on a second set of 200 documents. During each iteration, we measured performance of the NLP tool against manual annotations performed by our study team. At each step, we conducted a detailed error analysis of false negative and false positive errors when compared to the reference standard, which was used to adjust the labeling patterns and features. We used cross-validation to test the modified system on training and evaluation set combined. This iterative process of evaluation followed by error analysis and system modification was continued until the change in F1-measure between two sequential cross validations run on independent testing sets was less than $1 \%$. Once iterative development was complete, we evaluated tool performance on the final set of 200 documents.

Each $A B I$ test report often had multiple mentions of $A B I$ and $T B I$ values (e.g., body of the report and conclusion). We designed the NLP system to extract all mentions of right $A B I$, left $A B I$, right $T B I$ and left TBI in the annotated reference standard. Extracted values were considered as true positive if they exactly matched with the annotated set with regards to the index value, index type (ABI or TBI), and laterality (right or left). An extracted value was considered false positive if it did not match the annotated set on either the index value (e.g., 0.6 vs. 0.65), index type (ABI mislabelled as TBI) or laterality (e.g., right mislabelled as left). A false negative error was present when the NLP system completely missed an annotated value. We calculated precision (equivalent to positive predictive value), recall (equivalent to sensitivity) and F1-measure (harmonic mean of precision and recall) 
medRxiv preprint doi: https://doi.org/10.1101/2021.05.08.21256421; this version posted May 10, 2021. The copyright holder for this preprint (which was not certified by peer review) is the author/funder, who has granted medRxiv a license to display the preprint in perpetuity.

All rights reserved. No reuse allowed without permission.

separately for mentions of right $\mathrm{ABI}$, left $\mathrm{ABI}$, right $\mathrm{TBI}$ and left $\mathrm{TBI}$. We decided a priori that a precision, recall and F1-measure of $>0.8$ would be acceptable. ${ }^{23}$

\section{Validation of the NLP system at a patient-level}

After completing development and validation of the NLP system at a document level, we also assessed the performance of the NLP-extracted $\mathrm{ABI}$ and TBI values to identify patients with PAD when compared to structured chart review as the gold standard (criterion validity). For this step, we identified a random sample of 360 patients with an $\mathrm{ABI}$ test report (20 patients each from the 18 Veterans Integrated Service Networks [VISN]). Patients were included if the ABI test report was dated between January 1, 2016-June 30, 2017. As noted previously, many VA facilities use a common document title to report $A B I$ and non-ABI vascular studies. Since non-ABI vascular studies were incorported in NLP training, we also evaluated the ability of the NLP system to differentiate patients who underwent non-ABI vascular studies. Details of the cohort inclusion criteria are listed in the Appendix (eMethods Section 1.4)

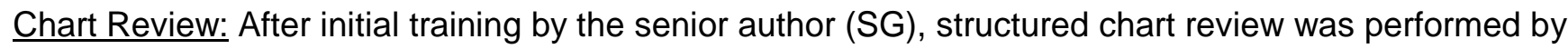
two physician trainees (AHQ and $\mathrm{BB})$. Medical records dating back 5 years prior to the first $\mathrm{ABI}$, and 6 months after the last $\mathrm{ABI}$ were selected for review. Data was extracted on demographics (age, sex, race), symptoms of PAD, diagnostic testing including other vascular imaging studies, and invasive treatment in a pre-designed chart abstraction form. Patients were classified as having lower extremity PAD if they met any one of the following criteria a) evidence of PAD on a confirmatory imaging study (e.g., angiography) b) physician documentation of PAD diagnosis in the EHR c) initiation or planned treatment of PAD (e.g., revascularization), d) prior history of PAD (e.g., revascularization), e) active leg symptoms in a patient with abnormal $A B I$ but did not return for follow up. Patients were classified as no PAD if a) there was no evidence of PAD on confirmatory imaging study b) physician documentation of no $P A D$ in the EHR, or $c)$ no confirmatory testing performed in a patient with normal $A B I(0.91-1.40)$. As noted above, $\mathrm{ABI}$ and $\mathrm{TBI}$ values alone were not used to determine PAD diagnosis during chart review except when patients with normal $A B I$ who did not return for follow up visit. To ensure reliability, a random sample of 25 charts that were reviewed by the two trainees were independently reviewed by 
medRxiv preprint doi: https://doi.org/10.1101/2021.05.08.21256421; this version posted May 10, 2021. The copyright holder for this preprint (which was not certified by peer review) is the author/funder, who has granted medRxiv a license to display the preprint in perpetuity.

All rights reserved. No reuse allowed without permission.

the senior author (SG). There was $100 \%$ agreement on the diagnosis of PAD variable between the chart reviewer and the senior author.

$\underline{A B I}$ Criteria for PAD: Based on the NLP-extracted ABI and TBI values, each patient was classified as having $P A D$ if the $A B I$ value was $\leq 0.9$, or $T B I$ value was $<0.7$ in any limb. The algorithm for $P A D$ classification using the NLP extracted ABI and TBI values is displayed in eFigure 1.

\section{RESULTS}

There was substantial variation in ABI test reports across VA facilities as illustrated in Figure 2A-2E. Although some $\mathrm{ABI}$ test reports contained largely complete, grammatical sentences $(\mathbf{2 A})$, most reports presented $\mathrm{ABI}$ and $\mathrm{TBI}$ values using a semi-structured format with a mixture of column headings, subheadings, and row labels that associate values to index type and laterality (2B-E). Additionally, some reports contained multiple values that appeared similar to but did not represent $A B I$ or $T B I$ such as 1) ratio of thigh to arm blood pressure $(2 \mathrm{~B} \& \mathbf{2 C}), 2)$ historical $A B I$ or $T B I$ values, or 3 ) a reference range for interpretation of index value ranges.

During the initial testing and cross validation of the NLP system on the first set of 200 documents, the overall precision was 0.72 , recall was 0.55 , and $\mathrm{F}-1$ measure was 0.63 . Iterative development, which involved error analysis and modification of regular expressions for text pattern recognition resulted in gradual performance improvement as the development set was expanded to encompass a total of 600 documents. Once development was complete and no further improvements were gained by further changes to the system, precision, recall, and F1-measure combined across index type and laterality was $0.92,0.94$, and 0.93 , respectively (Table 1 ). Addition of each set of location-dependent features resulted in incremental improvement in overall precision, recall, and F1measure, with the highest performance achieved with the inclusion of all feature sets (eTable 3).

The final performance of the NLP assessed is shown in Table 2. Overall precision was 0.85, recall was 0.93 , and the $\mathrm{F} 1$-measure was 0.89 . In some cases, the tool identified $\mathrm{ABI}$ values missed by the annotators, and, after correction for these oversights, overall precision, recall, and F1-measure 
medRxiv preprint doi: https://doi.org/10.1101/2021.05.08.21256421; this version posted May 10, 2021. The copyright holder for this preprint (which was not certified by peer review) is the author/funder, who has granted medRxiv a license to display the preprint in perpetuity.

All rights reserved. No reuse allowed without permission.

were slightly higher at $0.86,0.94$, and 0.90 , respectively. The F1-measure of the NLP system exceeded the inter-annotator agreement of the human reviewers (Appendix, eTable 4). The F1-measure was similar regardless of index type ( $\mathrm{ABI}$ or $\mathrm{TBI}$ ) or laterality (right or left). and ranged from 0.88 to 0.91 , but precision and recall varied by the index type. Recall was higher for $A B I$ than TBI values, while precision was higher for $\mathrm{TBI}$ compared to $\mathrm{ABI}$. Details regarding the false positive and false negative errors on the NLP system are included in the Appendix (eResults).

\section{$\underline{\text { Patient-level validation }}$}

Of the 360 patients randomly selected for the standardized chart review cohort, $99(27.5 \%)$ patients had a non-ABI vascular study. The NLP system correctly identified all of the 99 test reports as non-valid $\mathrm{ABI}$, and therefore they were excluded from the chart review. The characteristics of the remaining 261 patients are displayed in Table 3. The mean age was 69.6 years and $18.9 \%$ were Black, $5 \%$ were Hispanic. There was a high prevalence of co-morbidities in this cohort including hypertension, diabetes, chronic kidney disease, and heart failure.

A total of $130(49.8 \%)$ patients were categorized as PAD on chart review. The NLP system classified 117 (44.8\%) patients as PAD and 121 (46.3\%) patients without PAD. For 23 (8.8\%) patients, the NLP system was unable to extract any ABI or TBI values (9 patients with PAD and 14 patients without PAD on chart review). In the primary analysis, we included these patients and classified them as no PAD. The positive predictive of the NLP system for identifying PAD was $92.3 \%$, sensitivity was 83.1\% and specificity was $93.1 \%$ (Table 4). In the first post-hoc sensitivity analysis, we assumed that the 23 patients who couldn't be classified using the NLP system were completely misclassified, i.e., patients with PAD on chart review classified as No PAD using NLP and vice versa (i.e., worst case scenario). In this analysis, the positive predictive value was $82.4 \%$, sensitivity was $83.1 \%$ and specificity was $82.4 \%$. Excluding the 23 patients above (second post-hoc sensitivity analysis) yielded a positive predictive value of $92.3 \%$, sensitivity of $89.3 \%$, and specificity of $92.3 \%$. 
medRxiv preprint doi: https://doi.org/10.1101/2021.05.08.21256421; this version posted May 10, 2021. The copyright holder for this preprint (which was not certified by peer review) is the author/funder, who has granted medRxiv a license to display the preprint in perpetuity.

All rights reserved. No reuse allowed without permission.

\section{DISCUSSION}

Using $\mathrm{ABI}$ test reports from $94 \mathrm{VA}$ facilities that varied substantially in terms of document structure and complexity, we have successfully developed and validated an NLP system that can extract ABI and TBI values with a high degree of accuracy, with an overall precision of 0.85 , recall of 0.93 and an $\mathrm{F} 1$ measure of 0.89 . Furthermore, an algorithm based on NLP-extracted ABI and TBI values had a positive predictive value of $92.3 \%$ in identifying patients with PAD. The successful development of an NLP system for PAD detection in the VHA, the largest integrated health system in the U.S., provides an unprecedented opportunity to advance research and quality improvement efforts for PAD - a common and highly morbid condition that accounts for a substantial clinical and economic burden. Several of our findings are important and merit further discussion.

Traditional approaches that rely on billing codes for identifying PAD patients have been limited by poor sensitivity (<40\%) and specificity (60-70\%), which have hampered PAD research and quality improvement efforts. ${ }^{12,13}$ Accordingly, there has been a growing interest in developing NLP systems for PAD identification and many different approaches have been described. ${ }^{24-27}$ In a recent study, Weissler et al developed an NLP system using the EHR data at a single academic medical center. ${ }^{24}$ The NLP system determined the probability of PAD based on $A B I$ values, imaging studies and prior history of revascularization or non-traumatic amputation and was superior to a prior model that used billing codes with an overall positive predictive value of $74 \%$, specificity of $62 \%$, when sensitivity was set at $90 \%$. Other NLP studies for PAD identification have been conducted in highly selected populations (e.g., patients undergoing amputation ${ }^{26}$ or lower extremity angiograms ${ }^{25}$ ) and the utility of such models for broad clinical and investigational purposes remains unclear.

Our NLP system differs from prior applications which have primarily used a manual, rule-based approach that relies on the proximity of the concept of $\mathrm{ABI} / \mathrm{TBI}$ with their corresponding values and laterality. ${ }^{26}$ During the initial review of $A B I$ test reports, we found that many documents reported $A B I$ and $\mathrm{TBI}$ values in a tabular format. Extracting $\mathrm{ABI}$ and $\mathrm{TBI}$ values from such data require consideration of the complex interaction between column headings, sub-headings, and row labels which would make 
medRxiv preprint doi: https://doi.org/10.1101/2021.05.08.21256421; this version posted May 10, 2021. The copyright holder for this preprint (which was not certified by peer review) is the author/funder, who has granted medRxiv a license to display the preprint in perpetuity.

All rights reserved. No reuse allowed without permission.

a manual rule-based model challenging. ${ }^{28}$ To address this challenge, we designed our NLP system using a random forest-based, machine learning model, which is able to detect the relationship between the relative location of text patterns and their interaction with $A B I$ and $T B I$ values. $A$ major innovation of our NLP sysem is that vertical and horizontal alignment of text patterns rather than proximity alone which ensured a high degree of accuracy in identify $A B I$ and TBI values.

In addition to the accuracy of the NLP system in extracting individual ABI and TBI values, an algorithm based on the above values achieved high performance in identifying patients with PAD with an overall positive predictive value of $92.3 \%$ sensitivity of $83.1 \%$ and specificity of $93.1 \%$. Even under the assumption that the $23(8.8 \%)$ patients in whom the NLP system could not extract any ABI values were completely misclassified, the performance of our NLP system exceeds that of billing codes which have a sensitivity $<40 \%$ and specificity $<70 \%$. Our findings are consistent with prior population-based studies that have reported a high sensitivity $(80 \%)$ and specificity $(96 \%)$ of abnormal $\mathrm{ABI}(\leq 0.9)$ for identifying PAD. ${ }^{14}$ Despite their accuracy, $A B I$ and TBI values are not routinely available as discrete data elements in most EHRs, including the VHA and are often embedded within clinical documents as either unstructured text or containing semi-structured elements such as tables. Manual extraction of $A B I$ and $T B I$ is not feasible given the large volume of $A B I$ tests $(>50,000)$ performed each year in the VHA. Our NLP system will allow for obtaining information on ABI and TBI values efficiently, and the latter can be used for identifying patients with PAD with a high degree of accuracy.

Accurate automatic extraction of $\mathrm{ABI}$ and $\mathrm{TBI}$ values will permit identification of large cohort of PAD patients within the VA's integrated health system. Although the tool achieved a high positive predictive value, its performance may be further enhanced in the future with the incorporation of findings from imaging studies. Since the NLP tool was developed and validated using VHA data, it can be readily scaled to the national VHA with high fidelity that will promote the use of big data analytics for PAD research. In addition, the NLP system can be intergrated into evaluating PAD care delivery, identifying opportunities for improving care quality and setting the stage for interventions including 
medRxiv preprint doi: https://doi.org/10.1101/2021.05.08.21256421; this version posted May 10, 2021. The copyright holder for this preprint (which was not certified by peer review) is the author/funder, who has granted medRxiv a license to display the preprint in perpetuity.

All rights reserved. No reuse allowed without permission.

clinical trials to address current and emerging research questions. Thus, our findings have important implications for advancing PAD research and quality improvement efforts in the VHA.

The findings of our study should be interpreted in the context of the following limitations. First, even though we included documents from a large number of VA facilities, ABI test reports from 30\% of VA facilities could not be obtained. Many of these facilities scan the ABI test reports and store them as images making them unavailable in the VHA CDW for research purposes. Alternative strategies such as developing algorithms to identify PAD using clinic notes at these sites maybe developed. Second, our study was conducted using VHA data and therefore the accuracy of our tool on documents outside the VA remains untested. However, given the large variation in document structure and complexity included in the study, we believe that retraining the model on non-VA documents might be sufficient for optimizing the NLP system for non-VA sites. Third, among patients with a valid ABI, the NLP system was unable to extract $A B I$ and TBI values (and unable to classify PAD) in $8.8 \%$ patients (23 out of 261 ). Even under the assumption that these patients were completely misclassified, the performance of the NLP system exceeded that of PAD billing codes. Additional refinements to the NLP system may further reduce the proportion of patients in whom $A B I$ and TBI values cannot be extracted. Fourth, our NLP system was designed using random forest models to automate the identification of important feature interactions. It is possible that additional performance gains may be achieved using more advanced models (e.g., deep learning) that have the advantage of partially automating the generation of features and feature interaction. ${ }^{28-31}$ Finally, given that the VHA guidelines do not recommend screening $\mathrm{ABI}$ in asymptomatic patients, patients with undiagnosed or asymptomatic PAD would not be included as they are unlikely to undergo $\mathrm{ABI}$ testing.

In conlusion, we have successfully developed and validated an NLP system that can extract ABI and TBI values and identify patients with PAD within the VA's large integrated health system with a high degree of accuracy. Our work has important implications for advancing research and quality improvement efforts in the VHA and elsewhere. 
medRxiv preprint doi: https://doi.org/10.1101/2021.05.08.21256421; this version posted May 10, 2021. The copyright holder for this preprint (which was not certified by peer review) is the author/funder, who has granted medRxiv a license to display the preprint in perpetuity.

All rights reserved. No reuse allowed without permission.

\section{Funding}

This study was funded by the Veterans Affairs Health Services Research \& Development Pilot Grant (I21HX002365; PI: Girotra). The funding organization had no role in: 1) the design and conduct of the study; 2) collection, management, analysis, and interpretation of the data; 3) preparation, review, or approval of the manuscript; or 4) decision to submit the manuscript for publication. The views expressed here are those of the authors and do not represent the Department of Veterans Affairs. Dr. Girotra and Dr. Gobbel had full access to all the data in the study and take responsibility for the integrity of the data and the accuracy of the data analysis.

\section{Disclosures}

None of the authors have any financial disclosures pertinent to this article. 
medRxiv preprint doi: https://doi.org/10.1101/2021.05.08.21256421; this version posted May 10, 2021. The copyright holder for this preprint (which was not certified by peer review) is the author/funder, who has granted medRxiv a license to display the preprint in perpetuity.

All rights reserved. No reuse allowed without permission.

\section{REFERENCES}

1. Song P, Rudan D, Zhu Y, Fowkes FJI, Rahimi K, Fowkes FGR and Rudan I. Global, regional, and national prevalence and risk factors for peripheral artery disease in 2015: an updated systematic review and analysis. Lancet Glob Health. 2019;7:e1020-e1030.

2. Willey J, Mentias A, Vaughan-Sarrazin M, McCoy K, Rosenthal G and Girotra S. Epidemiology of lower extremity peripheral artery disease in veterans. J Vasc Surg. 2018;68:527-535 e5.

3. Criqui MH, Langer RD, Fronek A, Feigelson HS, Klauber MR, McCann TJ and Browner D. Mortality over a period of 10 years in patients with peripheral arterial disease. $N$ Engl $J$ Med. 1992;326:381-6.

4. Newman AB, Shemanski L, Manolio TA, Cushman M, Mittelmark M, Polak JF, Powe NR and Siscovick D. Ankle-arm index as a predictor of cardiovascular disease and mortality in the Cardiovascular Health Study. The Cardiovascular Health Study Group. Arterioscler Thromb Vasc Biol. 1999;19:538-45.

5. Resnick HE, Lindsay RS, McDermott MM, Devereux RB, Jones KL, Fabsitz RR and Howard BV. Relationship of high and low ankle brachial index to all-cause and cardiovascular disease mortality: the Strong Heart Study. Circulation. 2004;109:733-9.

6. Vogt MT, Cauley JA, Newman AB, Kuller LH and Hulley SB. Decreased ankle/arm blood pressure index and mortality in elderly women. JAMA. 1993;270:465-9.

7. Murabito JM, Evans JC, Larson MG, Nieto K, Levy D, Wilson PW and Framingham S. The ankle-brachial index in the elderly and risk of stroke, coronary disease, and death: the Framingham Study. Arch Intern Med. 2003;163:1939-42.

8. McDermott MM. Lower extremity manifestations of peripheral artery disease: the pathophysiologic and functional implications of leg ischemia. Circ Res. 2015;116:1540-50.

9. Hirsch AT, Hartman L, Town RJ and Virnig BA. National health care costs of peripheral arterial disease in the Medicare population. Vasc Med. 2008;13:209-15.

10. Mahoney EM, Wang K, Cohen DJ, Hirsch AT, Alberts MJ, Eagle K, Mosse F, Jackson JD, Steg PG, Bhatt DL and Investigators RR. One-year costs in patients with a history of or at risk for atherothrombosis in the United States. Circ Cardiovasc Qual Outcomes. 2008;1:38-45.

11. Mahoney EM, Wang K, Keo HH, Duval S, Smolderen KG, Cohen DJ, Steg G, Bhatt DL, Hirsch AT and Reduction of Atherothrombosis for Continued Health Registry I. Vascular hospitalization rates and costs in patients with peripheral artery disease in the United States. Circ Cardiovasc Qual Outcomes. 2010;3:642-51.

12. Fan J, Arruda-Olson AM, Leibson CL, Smith C, Liu G, Bailey KR and Kullo IJ. Billing code algorithms to identify cases of peripheral artery disease from administrative data. Journal of the American Medical Informatics Association : JAMIA. 2013;20:e349-54.

13. Hong Y, Sebastianski M, Makowsky M, Tsuyuki R and McMurtry MS. Administrative data are not sensitive for the detection of peripheral artery disease in the community. Vasc Med. 2016.

14. Aboyans V, Criqui MH, Abraham P, Allison MA, Creager MA, Diehm C, Fowkes FG, Hiatt WR, Jonsson B, Lacroix P, Marin B, McDermott MM, Norgren L, Pande RL, Preux PM, Stoffers HE, TreatJacobson D, American Heart Association Council on Peripheral Vascular D, Council on E, Prevention, 
medRxiv preprint doi: https://doi.org/10.1101/2021.05.08.21256421; this version posted May 10, 2021. The copyright holder for this preprint (which was not certified by peer review) is the author/funder, who has granted medRxiv a license to display the preprint in perpetuity.

All rights reserved. No reuse allowed without permission.

Council on Clinical C, Council on Cardiovascular N, Council on Cardiovascular R, Intervention, Council on Cardiovascular S and Anesthesia. Measurement and interpretation of the ankle-brachial index: a scientific statement from the American Heart Association. Circulation. 2012;126:2890-909.

15. Newman AB, Siscovick DS, Manolio TA, Polak J, Fried LP, Borhani NO and Wolfson SK. Anklearm index as a marker of atherosclerosis in the Cardiovascular Health Study. Cardiovascular Heart Study (CHS) Collaborative Research Group. Circulation. 1993;88:837-45.

16. Hirsch AT, Haskal ZJ, Hertzer NR, Bakal CW, Creager MA, Halperin JL, Hiratzka LF, Murphy WR, Olin JW, Puschett JB, Rosenfield KA, Sacks D, Stanley JC, Taylor LM, Jr., White CJ, White J, White RA, Antman EM, Smith SC, Jr., Adams CD, Anderson JL, Faxon DP, Fuster V, Gibbons RJ, Hunt SA, Jacobs AK, Nishimura R, Ornato JP, Page RL, Riegel B, American Association for Vascular S, Society for Vascular S, Society for Cardiovascular A, Interventions, Society for Vascular M, Biology, Society of Interventional R, Disease AATFoPGWCtDGftMoPWPA, American Association of C, Pulmonary R, National Heart L, Blood I, Society for Vascular N, TransAtlantic Inter-Society C and Vascular Disease F. ACC/AHA 2005 Practice Guidelines for the management of patients with peripheral arterial disease (lower extremity, renal, mesenteric, and abdominal aortic): a collaborative report from the American Association for Vascular Surgery/Society for Vascular Surgery, Society for Cardiovascular Angiography and Interventions, Society for Vascular Medicine and Biology, Society of Interventional Radiology, and the ACC/AHA Task Force on Practice Guidelines (Writing Committee to Develop Guidelines for the Management of Patients With Peripheral Arterial Disease): endorsed by the American Association of Cardiovascular and Pulmonary Rehabilitation; National Heart, Lung, and Blood Institute; Society for Vascular Nursing; TransAtlantic Inter-Society Consensus; and Vascular Disease Foundation. Circulation. 2006;113:e463-654.

17. Fowkes FG, Murray GD, Butcher I, Heald CL, Lee RJ, Chambless LE, Folsom AR, Hirsch AT, Dramaix M, deBacker G, Wautrecht JC, Kornitzer M, Newman AB, Cushman M, Sutton-Tyrrell K, Fowkes FG, Lee AJ, Price JF, d'Agostino RB, Murabito JM, Norman PE, Jamrozik K, Curb JD, Masaki KH, Rodriguez BL, Dekker JM, Bouter LM, Heine RJ, Nijpels G, Stehouwer CD, Ferrucci L, McDermott MM, Stoffers HE, Hooi JD, Knottnerus JA, Ogren M, Hedblad B, Witteman JC, Breteler MM, Hunink MG, Hofman A, Criqui MH, Langer RD, Fronek A, Hiatt WR, Hamman R, Resnick HE, Guralnik J and McDermott MM. Ankle brachial index combined with Framingham Risk Score to predict cardiovascular events and mortality: a meta-analysis. JAMA. 2008;300:197-208.

18. Aboyans V, Criqui MH, Denenberg JO, Knoke JD, Ridker PM and Fronek A. Risk factors for progression of peripheral arterial disease in large and small vessels. Circulation. 2006;113:2623-9.

19. Nicoloff AD, Taylor LM, Jr., Sexton GJ, Schuff RA, Edwards JM, Yeager RA, Landry GJ, Moneta GL, Porter JM, Homocysteine and Progression of Atherosclerosis Study I. Relationship between site of initial symptoms and subsequent progression of disease in a prospective study of atherosclerosis progression in patients receiving long-term treatment for symptomatic peripheral arterial disease. $J$ Vasc Surg. 2002;35:38-46; discussion 46-7.

20. South BR, Shen S, Leng J, Forbush TB, DuVall SL and Chapman WW. A prototype tool set to support machine-assisted annotation. Proceedings of the 2012 Workshop on Biomedical Natural Language Processing. 2012:130-139.

21. Frank E, Hall MA and Witten IH. The WEKA Workbench. Online Appendix for "Data Mining: Practical Machine Learning Tools and Techniques. 2016.

22. $\quad$ https://githubcom/gobbelg/RandomForestABI (Accessed May 5, 2021). 
medRxiv preprint doi: https://doi.org/10.1101/2021.05.08.21256421; this version posted May 10, 2021. The copyright holder for this preprint (which was not certified by peer review) is the author/funder, who has granted medRxiv a license to display the preprint in perpetuity.

All rights reserved. No reuse allowed without permission.

23. Derczynski L. Complementarity, F-score, and NLP Evaluation. Proceedings of the Tenth International Conference on Language Resources and Evaluation (LREC'16), May 2016; Portorož, Slovenia.261-266.

24. Weissler EH, Zhang J, Lippmann S, Rusincovitch S, Henao R and Jones WS. Use of Natural Language Processing to Improve Identification of Patients With Peripheral Artery Disease. Circ Cardiovasc Interv. 2020;13:e009447.

25. Savova GK, Fan J, Ye Z, Murphy SP, Zheng J, Chute CG and Kullo IJ. Discovering peripheral arterial disease cases from radiology notes using natural language processing. AMIA Annu Symp Proc. 2010;2010:722-6.

26. Alba P, Duvall S, Norvell D, Moore K, Czerniecki J and Patterson O. Ankle Brachial Index Extraction System. In: AMIA Annu Symp Proc. 2018.

27. Afzal N, Sohn S, Abram S, Scott CG, Chaudhry R, Liu H, Kullo IJ and Arruda-Olson AM. Mining peripheral arterial disease cases from narrative clinical notes using natural language processing. $J$ Vasc Surg. 2017;65:1753-1761.

28. Wu S, Roberts K, Datta S, Du J, Ji Z, Si Y, Soni S, Wang Q, Wei Q, Xiang Y, Zhao B and Xu H. Deep learning in clinical natural language processing: a methodical review. J Am Med Inform Assoc. 2020;27:457-470.

29. Hahn U and Oleynik M. Medical Information Extraction in the Age of Deep Learning. Yearb Med Inform. 2020;29:208-220.

30. Fu S, Chen D, He H, Liu S, Moon S, Peterson KJ, Shen F, Wang L, Wang Y, Wen A, Zhao Y, Sohn S and Liu H. Clinical concept extraction: A methodology review. J Biomed Inform. 2020;109:103526.

31. Wu Y, Rosenbloom ST, Denny JC, Miller RA, Mani S, Giuse DA and Xu H. Detecting abbreviations in discharge summaries using machine learning methods. AMIA Annu Symp Proc. $2011 ; 2011: 1541-9$. 


\section{FIGURE LEGENDS}

Figure 1. Flow diagram illustrating the steps used to extract ankle-brachial index values (ABls) and toe-brachial index values (TBIs) from ABI testing reports generated within Department of Veterans Affairs medical facilities. The machine learning and NLP-based extraction system uses two, separately trained random forest (RF) models to assign index type ( $\mathrm{BB}, \mathrm{TB}$, or neither) and laterality (left, right, or neither) to all values ranging from 0.0 to 2.0 in the document. Only values assigned to a specific index type and laterality are retained.

Figure 2. Five samples of $A B I$ test reports illustrating the range of formats used for documenting anklebrachial index values (ABIs) and toe-brachial index values (TBIs). There was substantial variation report format. In some (A), values were embedded in standard sentences, but ABls and TBls were commonly displayed using semi-structured, tabular formats that employed spaces and newline characters to define rows and columns (B-E). Various forms of row labels, column headings, and subheadings were used to indicate index type ( $\mathrm{ABI}$ or $\mathrm{TBI}$ ), laterality (left or right), and multiple other forms of information, such as pressures (B-E) and pressure ratios from the calf, thigh or other anatomical regions (B\&C). All samples shown are from electronic health records of the Department of Veterans Affairs and were used in the present study for testing of the ABI and TBI extraction tool. 
medRxiv preprint doi: https://doi.org/10.1101/2021.05.08.21256421; this version posted May 10, 2021. The copyright holder for this preprint (which was not certified by peer review) is the author/funder, who has granted medRxiv a license to display the preprint in perpetuity.

All rights reserved. No reuse allowed without permission.

Table 1 Cross-Validation-Based Performance of the ABI Extraction Tool on the Development Set

\begin{tabular}{|l|c|c|c|c|c|c|}
\hline Index Type and Laterality & TP & FP & FN & Precision & Recall & F1 \\
\hline ABI Right & 467 & 42 & 20 & 0.92 & 0.96 & 0.94 \\
\hline ABI Left & 449 & 37 & 29 & 0.92 & 0.94 & 0.93 \\
\hline TBI Right & 142 & 15 & 10 & 0.90 & 0.93 & 0.92 \\
\hline TBI Left & 128 & 10 & 13 & 0.93 & 0.91 & 0.92 \\
\hline Total & 1186 & 104 & 72 & 0.92 & 0.94 & 0.93 \\
\hline
\end{tabular}

$\boldsymbol{T P}$ - true positive mentions of index values; $\boldsymbol{F P}$ - false positive mentions; $\boldsymbol{F N}$ - false negative mentions 
medRxiv preprint doi: https://doi.org/10.1101/2021.05.08.21256421; this version posted May 10, 2021. The copyright holder for this preprint (which was not certified by peer review) is the author/funder, who has granted medRxiv a license to display the preprint in perpetuity.

All rights reserved. No reuse allowed without permission.

Table 2 Performance of Random Forest-based ABI Extraction Tool on the Final Testing Set

\begin{tabular}{|l|c|c|c|c|c|c|}
\hline Index Type and Laterality & TP & FP & FN & Precision & Recall & F1 \\
\hline ABI Right & 111 & 22 & 4 & 0.83 & 0.97 & 0.90 \\
\hline ABI Left & 108 & 24 & 6 & 0.82 & 0.95 & 0.88 \\
\hline TBI Right & 35 & 2 & 5 & 0.95 & 0.88 & 0.91 \\
\hline TBI Left & 32 & 2 & 6 & 0.94 & 0.84 & 0.89 \\
\hline Total & 286 & 50 & 21 & 0.85 & 0.93 & 0.89 \\
\hline
\end{tabular}

$\boldsymbol{T P}$ - true positive mentions of index values; $\boldsymbol{F P}$ - false positive mentions; $\boldsymbol{F} \boldsymbol{N}$ - false negative mentions 
medRxiv preprint doi: https://doi.org/10.1101/2021.05.08.21256421; this version posted May 10, 2021. The copyright holder for this preprint (which was not certified by peer review) is the author/funder, who has granted medRxiv a license to display the preprint in perpetuity.

All rights reserved. No reuse allowed without permission.

Table 3. Characteristics of Chart Review Cohort

\begin{tabular}{|c|c|}
\hline Variable & $\mathrm{N}=261$ \\
\hline Mean Age, years (SD) & $69.6(9.9)$ \\
\hline Male Sex & $256(98.1 \%)$ \\
\hline \multicolumn{2}{|l|}{ Race $^{*}$} \\
\hline White & $200(76.6 \%)$ \\
\hline Black & $49(18.9 \%)$ \\
\hline Other & $6(2.3 \%)$ \\
\hline Hispanic Ethnicity* & $13(5.0 \%)$ \\
\hline \multicolumn{2}{|l|}{ Symptoms } \\
\hline Claudication & $68(26.1 \%)$ \\
\hline Atypical leg pain & $60(23.0 \%)$ \\
\hline Rest pain or ulcer & $46(17.6 \%)$ \\
\hline None documented & 87 (33.3\%) \\
\hline Known history of PAD & $53(20.3 \%)$ \\
\hline \multicolumn{2}{|l|}{ Co-morbidities } \\
\hline Hypertension & $237(90.8 \%)$ \\
\hline Diabetes & $149(57.1 \%)$ \\
\hline Chronic Kidney disease & $83(31.8 \%)$ \\
\hline COPD & $117(44.8 \%)$ \\
\hline Heart failure & 77 (29.5\%) \\
\hline Prior history of MI & $29(11.1 \%)$ \\
\hline Cerebrovascular disease & $75(28.7 \%)$ \\
\hline Cancer & $68(26.1 \%)$ \\
\hline \multicolumn{2}{|l|}{$\mathrm{ABI}$ test results, Mean (SD) } \\
\hline Right $\mathrm{ABI}$ & $0.97(0.28)$ \\
\hline Left ABI & $1.00(0.25)$ \\
\hline Right TBI & $0.66(0.28)$ \\
\hline Left TBI & $0.66(0.24)$ \\
\hline
\end{tabular}

Numbers in the table represent $\mathrm{N}(\%)$ or Mean (SD).

Abbreviations: COPD: Chronic Obstructive Pulmonary Disease; MI: Myocardial Infarction; SD: standard deviation

${ }^{*}$ Race was unknown for 6 patients, ethnicity was unknown for 4 patients 
Table 4. Performance of the NLP system in identifying patients with PAD compared to structured chart review

\begin{tabular}{|l|c|c|c|}
\hline & \multicolumn{2}{|c|}{ Chart Review } & Total \\
\hline NLP System & $\underline{P A D}$ & $\underline{\text { No } P A D}$ & \\
\hline PAD & $108(\mathrm{~A})$ & $9(\mathrm{~B})$ & 117 \\
\hline No PAD & $13(\mathrm{C})$ & $108(\mathrm{D})$ & 121 \\
\hline Unable to classify & $9(\mathrm{E})$ & $14(\mathrm{~F})$ & 23 \\
\hline Total & $\mathbf{1 3 0}$ & $\mathbf{1 3 1}$ & $\mathbf{2 6 1}$ \\
\hline
\end{tabular}

Main Analysis (categorizing the 23 patients who couldn't be classified using NLP system as No PAD using NLP)

Positive Predictive Value:

Sensitivity:

Specificity:

$$
\begin{array}{ll}
108 \div 117 & =92.3 \% \\
108 \div 130 & =83.1 \% \\
(108+14) \div 131 & =93.1 \%
\end{array}
$$

Sensitivity analysis\#1 (assuming that the 23 patients who couldn't be classified using NLP were completely misclassified, i.e., 9 patients in cell $E$ with PAD on chart review were misclassified as no PAD using NLP, and 14 patients without PAD on chart review (cell F) were misclassified as PAD using NLP)

Positive Predictive Value:

Sensitivity:

Specificity:

$$
\begin{array}{ll}
108 \div(117+14) & =82.4 \% \\
108 \div 130 & =83.1 \% \\
108 \div 131 & =82.4 \%
\end{array}
$$

Sensitivity analysis \#2: (excluding the 23 patients who could not be classified using NLP system)

$\begin{array}{lll}\text { Positive Predictive Value: } & 108 \div 117 & =92.3 \% \\ \text { Sensitivity: } & 108 \div 121 & =89.3 \% \\ \text { Specificity: } & 108 \div 117 & =92.3 \%\end{array}$


medRxiv preprint doi: https://doi.org/10.1101/2021.05.08.21256421; this version posted May 10, 2021. The copyright holder for this preprint (which was not certified by peer review) is the author/funder, who has granted medRxiv a license to display the preprint in perpetuity.

All rights reserved. No reuse allowed without permission.

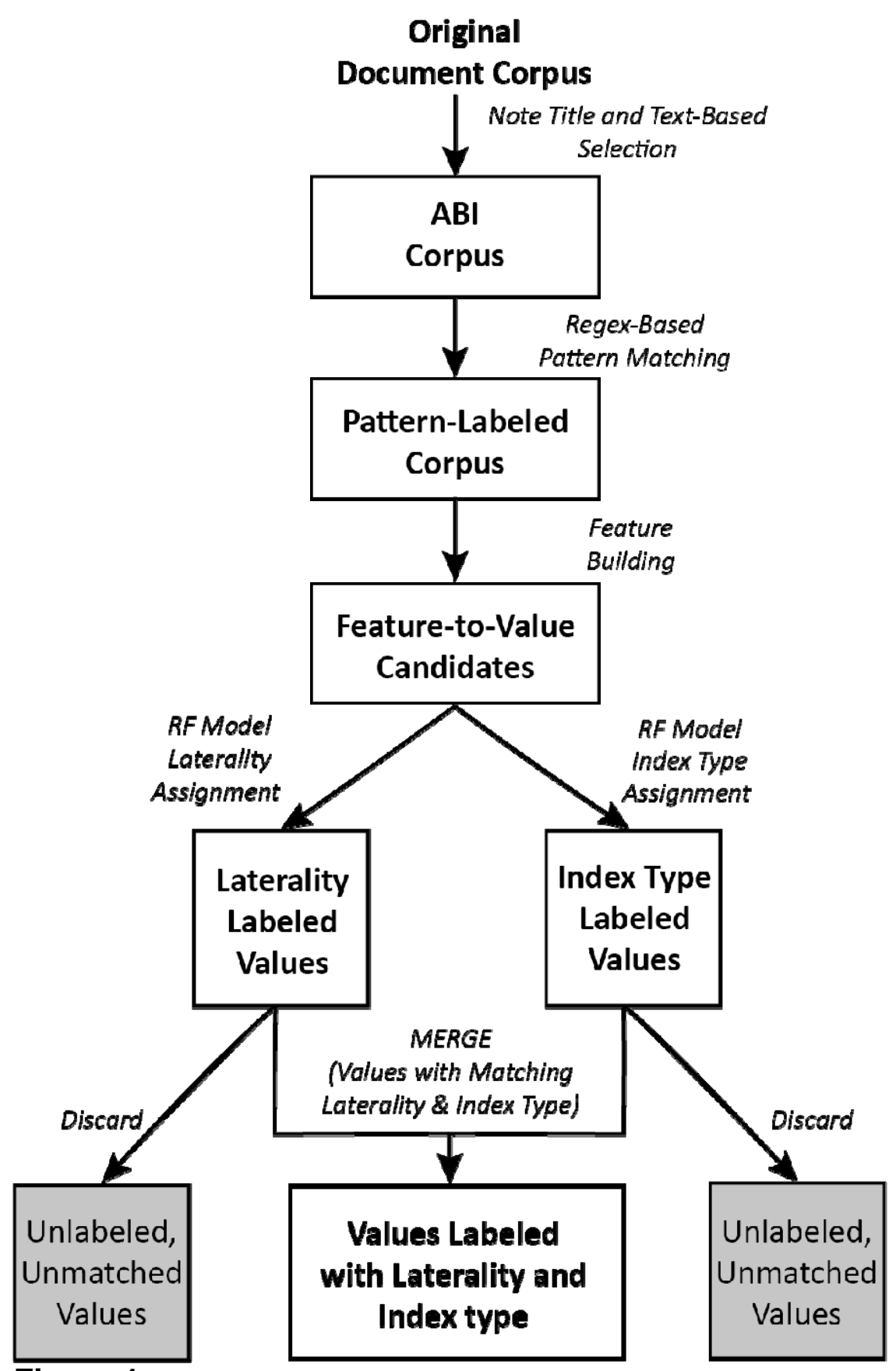

Figure 1 
medRxiv preprint doi: https://doi.org/10.1101/2021.05.08.21256421; this version posted May 10, 2021. The copyright holder for this preprint (which was not certified by peer review) is the author/funder, who has granted medRxiv a license to display the preprint in perpetuity.

All rights reserved. No reuse allowed without permission.

\section{Figure 2}

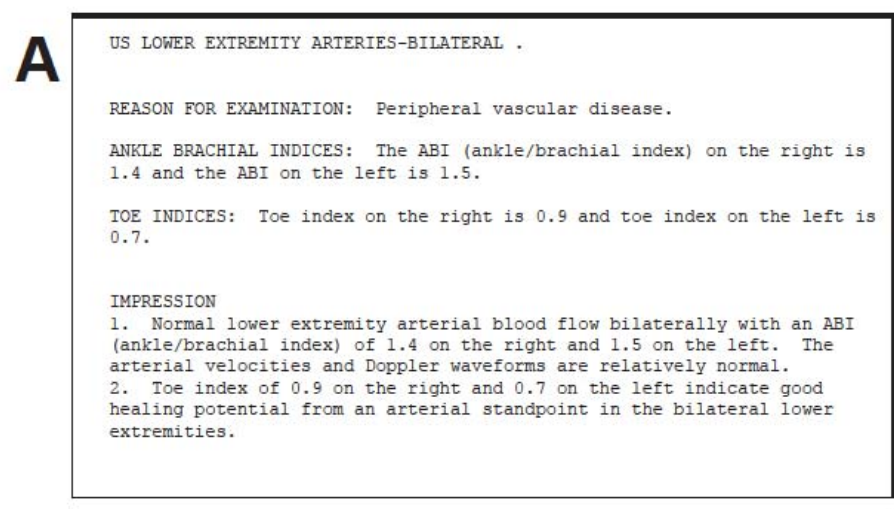

B

US SEgMental PResSURES, MULTI LEVELS

Right Leg:

$$
\begin{aligned}
& \text { Brachial: } 176 \\
& \text { High thigh: }>254-\text { NC } \\
& \text { Low thigh: } 189-1.07 \\
& \text { Calf: } 159-0.90 \\
& \text { PT ankle: } 145-0.82 \\
& \text { DP ankle: } 136-0.77 \\
& \text { Digit: } 190-1.08 \\
& \text { ABI: } 0.82
\end{aligned}
$$

Left Leg:

Brachial: 172

High thigh: $>254-$ NC

Low thigh: $188-1.07$

Calf: $243-1.38$

P1 ankie: $229-1.30$

DP ankle: $240-1.36$

ABI: 1.36

Value Interpretation for ABI:

Normal: 1.0 to 1.2

0.9 to 1.0

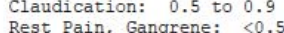

\begin{tabular}{|c|c|c|c|c|}
\hline \multicolumn{5}{|c|}{$\begin{array}{l}\text { SURG: VASCULAR SURGERY LAB CONSULT NOTE } \\
\text { SEGMENTAL PRESSURES W/PVR }\end{array}$} \\
\hline \multicolumn{5}{|c|}{$\begin{array}{l}\text { Brachial Pressures } \\
\text { Impression: } \mathrm{r} \text { lateral calf ulcer } \\
\text { duplex neg for dvt }\end{array}$} \\
\hline \multicolumn{5}{|l|}{$\begin{array}{ll}\mathrm{R} & 147 \\
\mathrm{~L} & 139\end{array}$} \\
\hline & PRE: & & & \\
\hline Upper Thigh: & & & & \\
\hline Lower Thigh: & 163 & 168 & 1.11 & 1.14 \\
\hline Calf: & 166 & 169 & 1.13 & 1.15 \\
\hline Ankle: & 149 & 103 & 1.01 & .70 \\
\hline
\end{tabular}

**Impression Text**:

The ankle-brachial index on the right lower extremity of 0.82 is in the range of mild peripheral arterial disease.

The ankle-brachial index of 1.36 of the left lower extremity is artifactually elevated. Ankle-brachial indices that exceed 1.3-1 are considered evidence of dense calcified atherosclerotic
D vascular lab procedure

Arterial pressure studies of both lower extremities with toe pressures:

\begin{tabular}{lllllll} 
& Brachial & dp & pt & ratio & digit & ratio \\
right & --- & $>220$ & $>220$ & $>1.0$ & 36 & .29 \\
left & 124 & 92 & 48 & .74 & 40 & .32 \\
& & & & & & \\
\hline
\end{tabular}

E

VASCULAR SURGERY LAB CONSULT

PALPABLE PEDAL PULSES BILATERALLY.

$\begin{array}{lcc} & \text { RIGHT } & \text { LEFT } \\ & & \\ & 119 & 126 \\ \text { BRACHIAL } & 145 & 145 \\ \text { ANKLE DP } & 146 & 147 \\ \text { ANKLE PT } & 118 & 128 \\ \text { GREAT TOE } & 1.15 & 1.15 \\ \text { ANKLE /ARM PRES INDEX DP } & 1.16 & 1.17 \\ \text { ANKLE/ARM PRES INDEX PT } & 1.16 & \\ & & \\ \text { DIGIT BRACHIAL INDEX } & \text { RIGHT: } 0.94 & \text { LEFT: } 1.02\end{array}$

Results for the RIGHT lower extremity

XX_are within normal range.

- show evidence of perlpheral arterial disease.

- are inconclusive.

Results for the LEFT lower extremity

$\mathrm{XX}$ are within normal range.

- show evidence of peripheral arterial disease.

- are inconclusive. 
medRxiv preprint doi: https://doi.org/10.1101/2021.05.08.21256421; this version posted May 10, 2021. The copyright holder for this preprint (which was not certified by peer review) is the author/funder, who has granted medRxiv a license to display the preprint in perpetuity.

All rights reserved. No reuse allowed without permission. 